\title{
PENGGUNAAN VIDEO BERBASIS TEKS DAN KERANJANG BAHASA UNTUK MENINGKATKAN KEMAMPUAN SISWA DALAM MENGANALISIS ASPEK KEBAHASAAN LAPORAN HASIL OBSERVASI
}

\author{
Sugiarti, Arti Prihatini, Fida Pangesti \\ FKIP Universitas Muhammadiyah Malang, Indonesia \\ Email: atika_umm@yahoo.co.id
}

\begin{abstract}
ABSTRAK
Penelitian ini bertujuan mendeskripsikan (1) penggunaan video berbasis teks dan keranjang bahasa untuk meningkatkan kemampuan siswa dalam menganalisis aspek kebahasaan teks laporan hasil observasi dan (2) peningkatan kemampuan siswa dalam menganalisis aspek kebahasaan laporan hasil observasi dengan menggunakan video berbasis teks dan keranjang bahasa. Penelitian ini merupakan penelitian tindakan kelas yang terdiri atas siklus-siklus yang dihentikan jika $85 \%$ siswa memenuhi kriteria kelulusan minimal (KKM) 75. Subjek penelitian ini adalah siswa kelas X MIPA 2 SMAN 7 Malang sejumlah 24 siswa. Data penelitian ini adalah deskripsi proses penggunaan video berbasis teks dan keranjang bahasa dan hasil belajar siswa pada analisis aspek kebahasaan laporan hasil observasi. Teknik pengumpulan data dilakukan dengan observasi, dokumentasi, wawancara, dan perekaman. Analisis data dilakukan pada proses dan hasil belajar siswa pada siklus 1 dan siklus 2. Hasil penelitian menunjukkan bahwa pada siklus 1, penggunaan video berbasis teks dalam diskusi kelompok dapat menstimulus siswa dalam menganalisis aspek kebahasaan, tetapi analisis kurang detail dan hasilnya belum optimal karena rata-rata hasil belajar siswa di bawah KKM, yakni 74,375 (kata), 70 (frasa), 69,95 (kalimat), dan 75 (kesalahan berbahasa). Pada siklus 2, penggunaan video berbasis teks dan keranjang bahasa dengan model permainan berkelompok berdampak pada keterlibatan siswa secara aktif, tepat, dan cepat dalam menganalisis aspek kebahasaan laporan hasil observasi (jenis kata, jenis frasa, jenis kalimat, dan kesalahan berbahasa). Pada akhirnya, kemampuan siswa dalam menganalisis aspek kebahasaan meningkat antara 10-14\%, yakni 82.5 (kata), 80 (frasa), 76.75 (kalimat), dan 75 (kesalahan berbahasa).
\end{abstract}

Kata Kunci: Media Pembelajaran, Aspek Kebahasaan, Laporan Hasil Observasi

\begin{abstract}
This study aims to describe (1) the use of text-based videos and language baskets to improve students' ability to analyze linguistic aspects of the observation report text and (2) increase students' ability to analyze linguistic aspects of observation report text using textbased videos and language basket. This research is a classroom action research consisting of discontinued cycles if $85 \%$ of students fulfill the minimum learning-outcome criteria 75. The subjects of this study are 25 students of class X MIPA 2, SMAN 7 Malang. The data is a description of the process of using text-based videos and language basket and student learning outcomes of linguistic aspects analysis of the observation report text. Data collection techniques are carried out by observation, documentation, interview, and recording. Data analysis was carried out on the process and student learning outcomes in first cycle and second cycle. The results showed that in first cycle, the use of text-based videos with group discussions can stimulate students to analyze linguistic aspects, but the analysis was not detailed and the results were not optimal because the average of student learning outcomes under minimum learning-outcome criteria, namely 74.375 (words), 70 (phrases), 69.95 (sentences), and 75 (language errors). In second cycle, the use of text-based videos and language baskets with group play models have an impact on student involvement actively, precisely, and fast to analyze linguistic aspects of observation report text (word types, phrase types, sentence types, and language errors). In second cycle, students' ability to analyze linguistic aspects increased between 10-14\%, namely 82.5 (words), 80 (phrases), 76.75 (sentences), and 75 (language errors).
\end{abstract}

Keywords: Learning Media, Linguistic Aspects, Observation Report Text 


\section{PENDAHULUAN}

Bahasa berperan sentral dalam perkembangan intelektual, sosial, dan emosional peserta didik. Bahasa juga merupakan penunjang keberhasilan dalam mempelajari semua bidang studi. Pembelajaran bahasa diharapkan dapat membantu peserta didik mengenal dirinya, budayanya dan budaya orang lain, mengemukakan gagasannya dan perasaannya, dan berpartisipasi dalam masyarakat yang menggunakan bahasa tersebut. Oleh karena itu, pembelajaran bahasa Indonesia diarahkan untuk meningkatkan kemampuan peserta didik untuk berkomunikasi dalam bahasa Indonesia secara baik dan benar, baik secara lisan maupun tulisan serta menumbuhkan apresiasi terhadap hasil karya sastra Indonesia (Muamar dalam Efendi, 2008:316).

Pembelajaran bahasa merupakan sarana penting untuk meningkatkan keterampilan siswa dalam menulis dan menganalisis persoalan bahasa. Penguasaan bahasa yang baik dapat membantu seseorang untuk mengungkapkan diri dan menanggapi apa yang terjadi. Kedua kemampuan ini menyebabkan pembelajar bahasa menjadi berinisiatif dan kreatif. Pembelajar bahasa mampu menguasai bahasa secara aktif dan mempermudah pemberdayaan dimensi vertikal dan horisontal dari hakikat bahasa secara efektif (Fernandez dalam (Efendi, 2008a). Pembelajaran bahasa membelajarkan peserta didik memiliki keterampilan berbahasa baik secara tertulis maupun lisan. Selain itu, juga menguasai bahasa Indonesia yang baik dan benar sesuai dengan tujuan dan fungsinya.

Peningkatan hasil belajar dipengaruhi oleh faktor-faktor tertentu yang berkaitan dengan aspek pedagogis, seperti pendekatan pembelajaran, model pembelajaran, materi, media pembelajaran, penilaian pembelajaran, dan faktor lainnya. Berkaitan dengan hal tersebut, Gilakjani dan Ahmadi (2011: 469) menyatakan bahwa untuk mencapai tujuan utama dari hasil belajar siswa, diperlukan pengunaan kombinasi antara metode pembelajaran dan pengelolaan lingkungan kelas untuk menstimulus pembelajaran yang interaktif. Di antara faktor-faktor tersebut, media pembelajaran memiliki peran penting untuk meningkatkan hasil belajar. Hal itu disebabkan oleh peran media yang dapat menjadi daya tarik bagi siswa untuk menambah minat belajarnya. Selain itu, media juga dapat membantu guru dalam menyampaikan materi.

Seiring dengan perkembangan teknologi dan informasi yang pesat, media dapat diciptakan dengan memanfaatkan teknologi tersebut. Wujud medianya dapat beraneka ragam bergantung pada tujuan guru dalam memanfaatkan teknologi tersebut. Penciptaan media pembelajaran berbasis teknologi tersebut diharapkan dapat menjadi motivasi ekstrinsik yang dapat menarik perhatian siswa untuk mengikuti pembelajaran. Sebagaimana dikemukakan Santrock (2012: 434) bahwa teknologi saat ini dapat dijadikan sebagai alat untuk memotivasi siswa dan dapat membantu proses pembelajaran.

Dalam pembelajaran bahasa antara cipta, rasa, dan karsa penguasaan bahasa menjadi penting (Sugiarti, 2016). Dalam konteks ini, pembelajaran bahasa harus mampu menciptakan generasi yang mempunyai kecerdasan intelektual maupun emosional dalam kerangka membangun kualitas sumber

Sugiarti, Arti Prihatini, Fida Pangesti, Penggunaan Video Berbasis Teks dan Keranjang Bahasa untuk Meningkatkan Kemampuan Siswa dalam Menganalisis Aspek Kebahasaan Laporan Hasil 
daya manusia. Dengan demikian, dapat dikatakan bahwa pembelajaran bahasa berkontribusi signifikan dalam meningkatkan intektual untuk menguasai keilmuan di berbagai bidang. Hal ini dapat diperhatikan bahwa bahasa merupakan muara/sumber dari segala informasi yang menggerakkan roda kehidupan.

Bahasa terdiri atas satuan-satuan/ aspek-aspek kebahasaan dari yang kecil hingga besar, yaitu kata, frasa, dan kalimat. Kata merupakan satuan bahasa yang dapat berupa kata benda (nomina), kata kerja (verba), kata sifat (ajektiva), dan kata bilangan (numeralia). Sneddon (2010:132) menyatakan bahwa kata benda (nomina) merepresentasikan makhluk hidup, nama tempat, barang, dan hal abstrak, misalnya bola, apel, kambing, paman, Malang, dan kebahagiaan. Kata kerja merepresentasikan suatu tindakan atau keadaan, seperti membaca dan tidur. Sneddon (2010:65) menjelaskan bahwa kata kerja memiliki keterkaitan dengan kata benda, kata sifat, dan jenis kata lainnya. Hal itu disebabkan oleh kata kerja yang dapat berfungsi sebagai predikat yang dapat menentukan subjek dan objek yang dapat menyertainya. Kata sifat (ajektiva) merepresentasikan ciri-ciri atau sifat yang melekat pada sesuatu. Sneddon (2010:180), menjelaskan bahwa kata sifat pada umumnya menjelaskan karakteristik dari kata benda, seperti bagus, cantik, hijau. Sementara itu, kata bilangan merepresentasikan jumlah atau hasil suatu penghitungan, seperti 1, 2, setengah $\mathrm{kg}$, dan seabad.

Setelah kata, satuan kebahasaan yang lebih besar adalah frasa, yakni gabungan kata yang terdiri atas inti frasa dan penjelasnya. Garim (2017:91) menyebutkan terdapat dua jenis frasa berdasarkan fungsinya, yaitu frasa endosentris dan frasa eksosentris. Frasa endosentris terdiri atas katakata yang memiliki makna sendiri (kata bebas), seperti apel hijau, meja belajar. Sementara itu, frasa eksosentris terdiri atas kata yang memiliki makna sendiri (kata bebas) dan kata yang tidak memiliki makna sendiri (kata tugas), seperti di sekolah (di: kata tugas, sekolah: kata bebas).

Setelah kata dan frasa, aspek kebahasaan yang lebih besar adalah kalimat. Kalimat memiliki informasi yang utuh. Kalimat memiliki ciri khusus, yakni bersifat predikatif atau memiliki predikat. Berdasarkan jumlah predikatnya, kalimat dikategorikan menjadi dua, yaitu kalimat simpleks dan kalimat kompleks. Kalimat simpleks hanya memiliki satu predikat utama atau yang dijelaskan Sneddon (2010:345) bahwa kalimat simpleks memiliki satu klausa bebas. Contohnya adalah Yoga $(S)$ melakukan $(P)$ penelitian $(O)$. Di sisi lain, kalimat kompleks merupakan kalimat yang memiliki predikat lebih dari satu sehingga dapat dikatakan bahwa kalimat kompleks memiliki dua klausa, klausa bebas dan atau klausa terikat. Kalimat kompleks memiliki ciri khusus, yakni konjungsi atau kata hubung, seperti jika, karena, agar, meskipun, sehingga, tetapi, dan sebagainya. Contohnya adalah Jika (konjungsi) data (S) sudah jenuh $(P)$, pengumpulan data (S) dihentikan (P). Klausa jika data sudah jenuh adalah klausa terikat karena maknanya tidak utuh sehingga tidak dapat berdiri sendiri sebagai kalimat, sedangkan klausa pengumpulan data dihentikan merupakan klausa bebas karena maknanya utuh sehingga dapat berdiri sendiri sebagai kalimat. 
Berdasarkan wawancara yang dilakukan terhadap guru bahasa Indonesia di SMAN 7 Malang, terdapat beberapa masalah yang dihadapi guru di kelas $\mathrm{X}$ yang berkaitan dengan media dan hasil belajar siswa. Pertama, teks laporan hasil observasi (LHO) dilakukan pada awal siswa masuk kelas $\mathrm{X}$, tetapi teks LHO tersebut merupakan materi yang paling sulit dibandingkan teks lainnya di kelas X. Kedua, aspek kebahasaan merupakan materi LHO yang sulit dipahami siswa, misalnya yang berkaitan dengan kata, frasa, dan kalimat. Ketiga, siswa memiliki minat belajar yang kurang sehingga berpengaruh pada hasil belajarnya. Keempat, guru melaksanakan RPP yang didampingi Unit Kegiatan Belajar Mandiri (UKBM) sehingga guru tidak memiliki ruang untuk melakukan inovasi. Hal itu disebabkan oleh semua siswa memiliki UKBM itu sehingga jika ada inovasi pada RPP dan UKBM, maka guru harus mengubah RPP dan UKBM itu juga serta membagikannya pada semua siswa. Kelima, media yang digunakan guru belum memanfaatkan teknologi secara optimal karena guru hanya menggunakan buku teks saja. Berkaitan dengan hal itu, solusi guru untuk mengatasi hal itu adalah dengan tutor sebaya yang dilakukan siswa yang telah selesai mengerjakan UKBM-nya untuk mengajari siswa lain yang masih tertinggal mengerjakan UKBM-nya.

Dalam konteks komunikasi bahasa memegang peranan penting, bahasa dapat diwadahi dimana saja sesuai dengan penggunanya. Dalam beberapa hal bahasa dapat ditempatkan pada penamaan bank menjadi bank bahasa. Bank bahasa yang dimaksud adalah tempat yang dapat digunakan untuk menyimpan aspek-aspek kebahasaan yang terkait dengan kata, frasa, klausa, kalimat, paragraf. Dalam model pembelajaran bank bahasa dapat digunakan sarana media pembelajaran yang dapat membantu anak untuk belajar aspek-aspek kebahasaan. Di samping itu, bank bahasa digunakan untuk menampung aspek-aspek kebahasaan tersebut agar siswa mudah mengidentifikasi persoalan digunakanlah keranjang dengan diberi inisial keranjang kata yang dapat dikategori atas jenis kata benda, kata kerja, kata sifat, kata bilangan. Selain itu, juga disediakan keranjang frasa yang menampung gabungan dua kata atau lebih yang tidak melebihi batas fungsi (S, P, O, K) dikategorikan menjadi frase endosentris dan frase eksosentris. Demikian pula pada kalimat disediakan pula pola kalimat simplek dan kalimat komplek. Bepergian ke bank bahasa siswa dapat mengambil kartu kata, frasa, atau kalimat dan memasukkan ke masing-masing keranjang yang tersedia. Penggunaan bank dan keranjang bahasa tersebut didesain dalam bentuk permainan sederhana agar siswa dapat belajar dalam situasi yang nyaman dan menyenangkan. Sehubungan dengan hal itu, Arends (2015:161) menjelaskan siswa termotivasi untuk berusaha dengan keras dalam lingkungan belajarnya ketika tugas pembelajarannya disajikan secara nyaman.

Dalam penggunaan media bank dan keranjang bahasa ini dipadu dengan media video yang diunggah di youtube tentang materi teks Laporan Hasil Observasi (LHO). Materi disusun secara sistematis sehingga memudahkan siswa dalam mempelajari materi. Materi ini didesain dalam bentuk video yang diunggah di youtube karena merespon perkembangan IT dalam konteks

Sugiarti, Arti Prihatini, Fida Pangesti, Penggunaan Video Berbasis Teks dan Keranjang Bahasa untuk Meningkatkan Kemampuan Siswa dalam Menganalisis Aspek Kebahasaan Laporan Hasil 
digitalisasi. Dengan demikian siswa dapat belajar dimana saja sesuai dengan keinginannya. Simunic, Kerner, dan Gajovic (2018:178) menyatakan bahwa teknologi dengan kemajuannya yang luar biasa sangat efektif digunakan dalam membentuk cakrawala pengetahuan siswa. Teknologi menyediakan sarana bagi pengguna dan sistem untuk mengelola konten pengetahuan siswa sehingga teknologi dapat berperan sebagai digital mediators.

Peran guru dituntut untuk menciptakan pembelajaran yang mampu membangkitkan peserta didik untuk berkreasi secara individu maupun kelompok. Di samping itu, siswa mampu membangun komunikasi yang baik, menunjukkan sikap mandiri sehingga potensi masing-masing individu dapat digali dan ditumbuhkembangkan secara maksimal. Hal itu dapat dilakukan apabila guru melakukan berbagai strategi/teknik untuk membuat suasana pembelajaran yang menarik dan menyenangkan bagi peserta didik. Sebagaimana dikemukakan Xhemajli (2016:31) bahwa guru adalah pembangkit interaksi dasar dengan muridnya yang hanya dapat dicapai melalui pembelajaran yang terorganisasi dengan baik.

Berdasarkan latar belakang tersebut, rumusan penelitian dapat dikemukakan sebagai berikut.

(1) Bagaimana penggunaan video berbasis teks dan keranjang bahasa untuk meningkatkan kemampuan siswa dalam menganalisis aspek kebahasaan teks laporan hasil observasi pada siswa X MIPA 2 SMAN 7 Malang?

(2) Bagaimana peningkatan kemampuan siswa dalam menganalisis aspek kebahasaan teks laporan hasil observasi dengan menggunakan video berbasis teks dan keranjang bahasa pada siswa X MIPA 2 SMAN 7 Malang?

\section{METODE}

Penelitian ini adalah penelitian tindakan kelas (PTK) karena bertujuan untuk mengatasi permasahalan dalam pembelajaran laporan teks hasil observasi dengan menggunakan cara atau solusi. Data penelitian ini terdiri atas dua jenis, yaitu (1) deskripsi penggunaan video berbasis teks dan keranjang bahasa dan (2) hasil belajar siswa dalam analisis aspek kebahasaan teks laporan observasi. Data bersumber dari proses pembelajaran laporan hasil observasi dengan menggunakan video berbasis teks dan keranjang bahasa pada siklus 1 dan siklus 2 serta nilai siswa pada aspek kebahasaan teks laporan hasil observasi. Selain itu, data juga bersumber dari hasil wawancara dan hasil observasi yang dilakukan oleh peneliti dan guru terhadap pembelajaran yang berlangsung. Lokasi penelitian di SMAN 7 Malang. Subjek penelitian adalah 24 siswa kelas X MIPA 2. Penelitian ini menggunakan empat jenis teknik pengumpulan data, yaitu observasi, wawancara, dokumentasi, dan perekaman. Analisis data dilakukan dilakukan melalui beberapa tahap, yaitu (1) reduksi data, (2) penyajian data proses dan hasil penggunaan video berbasis teks dan keranjang bahasa pada siklus 1 dan siklus 2, dan (3) penarikan kesimpulan dan verifikasi temuan.

\section{HASIL DAN PEMBAHASAN}

Hasil dan pembahasan pada artikel ini dijelaskan dalam dua bagian, yaitu (1) penggunaan video berbasis teks dan keranjang bahasa untuk 
meningkatkan kemampuan siwa dalam menganalisis aspek kebahasaan teks laporan hasil observasi pada siswa kelas X SMAN 7 Malang dan (2) peningkatan kemampuan siswa dalam menganalisis aspek kebahasaan teks laporan hasil observasi dengan menggunakan video berbasis teks dan keranjang bahasa pada siswa X MIPA 2 SMAN 7 Malang.

\section{Penggunaan Video Berbasis Teks dan Keranjang Bahasa untuk Meningkatkan Kemampuan Siswa dalam Menganalisis Aspek Kebahasaan Teks Laporan Hasil Observasi pada Siswa Kelas X MIPA 2 SMAN 7 Malang}

Pada bagian ini, dijelaskan proses pembelajaran yang dilakukan pada siklus 1 dan siklus 2. Pada siklus 1 , guru menayangkan video berbasis teks melalui LCD untuk mengingatkan kembali tentang materi teks laporan hasil observasi yang telah dipelajari. Siswa menyimak tayangan laporan hasil observasi Museum Tekstil. Pada proses ini, beberapa siswa mencatat informasi penting dalam video. Dosen mengulang penayangan video agar siswa lebih menyerap informasi di dalamnya. Setelah itu, para siswa membentuk kelompok untuk berdiskusi yang terdiri atas 4-5 siswa. Setiap kelompok menerima steroform yang telah tertempel di dinding, kertas lipat warna-warni, double tip, gunting, bendera bertanda silang (X), serta bendera bertanda klik $(\sqrt{ })$.

Siswa membentuk kelompok untuk mengidentifikasi isi, struktur, dan aspek kebahasaan berupa sifat bahasa yang digunakan atau contohcontoh unit bahasa (kata, frasa, klausa, atau kalimat) yang ada dalam video. Dalam kelompok, siswa berdiskusi, menuliskan di kertas warna-warni, dan menempelkannya di steroform secara menarik dan kreatif. Setiap kelompok secara bergantian menjelaskan hasil pekerjaan kelompoknya. Setelah setiap kelompok bergantian menyampaikan hasil pekerjaannya, guru memberikan apresiasi positif terhadap usaha yang dilakukan siswa. Guru menanggapi penjelasan setiap kelompok. Guru juga memberikan penguatan materi agar para siswa lebih memahami tentang isi, struktur, dan aspek kebahasaan teks laporan hasil observasi. Beberapa siswa dan bertanya tentang materi yang belum dipahami.

Berdasarkan refleksi pada siklus 1, para siswa menemukan beberapa hal, yaitu (1) bahasa yang digunakan adalah bahasa yang formal dan baku, (2) kata adalah, merupakan, dan ialah digunakan pada kalimat definisi, serta (3) kata yaitu, seperti, dan antara lain digunakan dalam menyebutkan kelompok informasi pada struktur deskripsi bagian. Akan tetapi, aspek kebahasaan secara lebih terperinci tentang kata, frasa, klausa, dan kalimat belum ditemukan oleh masingmasing kelompok. Selain itu, para siswa kebingungan dalam memahami instruksi dari guru karena belum disertai contoh pengerjaannya. Para siswa juga belum sepenuhnya terlibat aktif dalam pembelajaran. Oleh karena itu, dibutuhkan tindak lanjut untuk meningkatkan proses dan hasil belajar siswa pada siklus 2 .

Pada proses pembelajaran siklus 2, siswa diarahkan untuk kritis terhadap penggunaan bahasa dalam teks laporan hasil observasi. Siswa membentuk kelompok yang terdiri atas 5-6 siswa. Setiap kelompok diarahkan untuk menempati posisi yang telah

Sugiarti, Arti Prihatini, Fida Pangesti, Penggunaan Video Berbasis Teks dan Keranjang Bahasa untuk Meningkatkan Kemampuan Siswa dalam Menganalisis Aspek Kebahasaan Laporan Hasil 
ditetapkan untuk melakukan permainan berkelompok dengan menggunakan keranjang bahasa. Setiap siswa dalam kelompok berbaris dan secara bergantian mengambil empat kartu kata, frasa, atau kalimat secara acak yang ada dalam kotak yang bernama 'bank bahasa'. Setelah

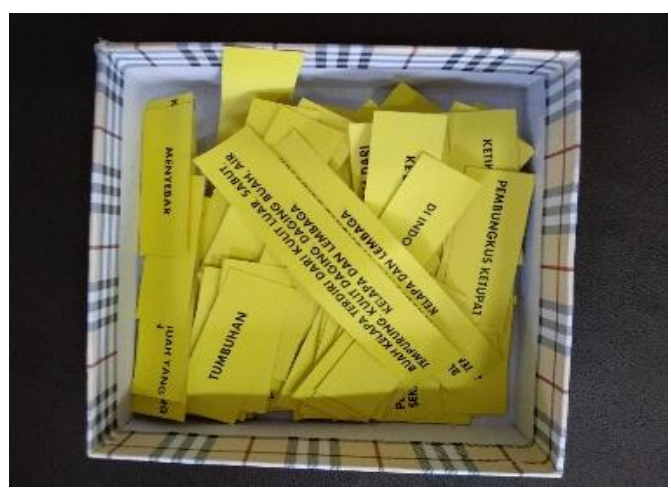

Gambar 1. Bank Bahasa

Dalam penggunaan media bank dan keranjang bahasa ini dipadu dengan media video berbasis teks yang diunggah di youtube tentang materi teks Laporan Hasil Observasi (LHO). Materi disusun secara sistematis sehingga memudahkan siswa dalam mempelajari materi. Materi ini didesain secara online di youtube berupa video karena merespon perkembangan IT dalam konteks digitalisasi. Dengan demikian siswa dapat belajar dimana saja sesuai dengan keinginannya.

Setelah memasukkan kartu dalam keranjang bahasa, siswa dalam kelompok

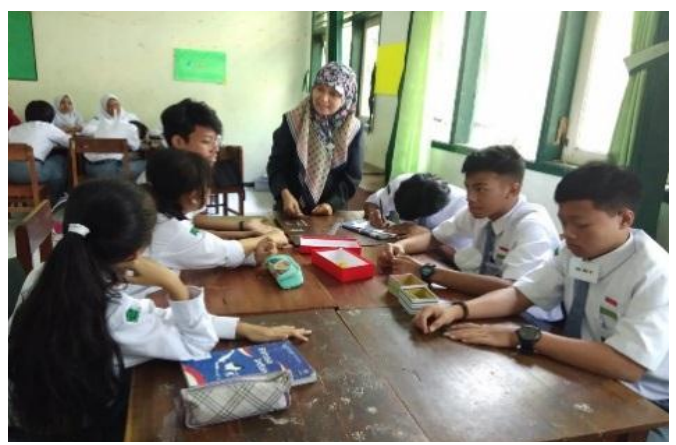

Gambar 3. Dosen Menjawab Pertanyaan Siswa itu, siswa dapat mengambil kartu kata, frasa, atau kalimat dan memasukkan ke masing-masing keranjang yang tersedia, yakni keranjang kata, keranjang frasa, dan keranjang kalimat sesuai dengan klasifikasi jenis kata, frasa, dan kalimat.

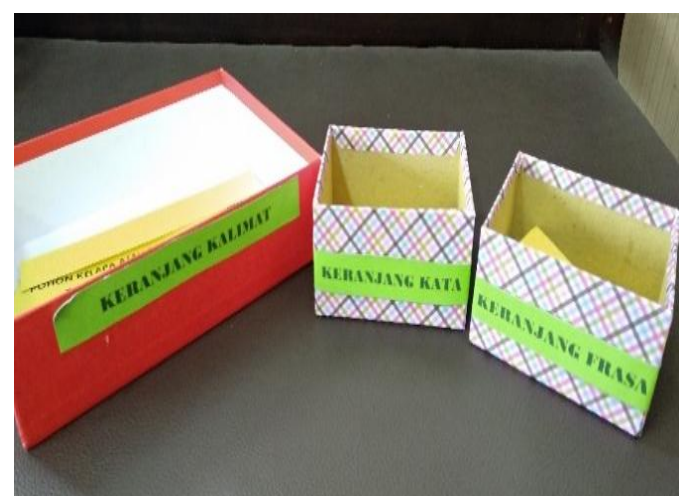

Gambar 2. Keranjang Bahasa

menganalisis kartu kata, kartu frasa, dan kartu kalimat dalam lembar kerja yang diberikan pada setiap kelompok. Siswa juga diminta untuk mencari contoh lain kata, frasa, dan kalimat dari teks laporan hasil observasi yang disertakan pada lembar kerja tersebut. Setelah itu, Siswa dalam kelompok menunjukkan empat kesalahan berbahasa dan menyampaikan bentuk perbaikannya. Pada kegiatan ini, sebagian besar kelompok mampu menemukan kesalahan pada teks laporan hasil observasi pada tataran ejaan dan struktur kalimat.

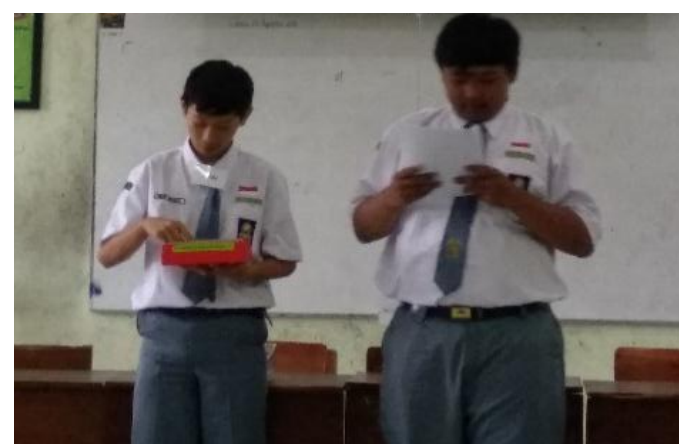

Gambar 4. Siswa Presentasi

JINoP (Jurnal Inovasi Pembelajaran), Volume 4, Nomor 2 , November 2018, hal 172-186 
Setelah selesai presentasi, siswa dan guru mengevaluasi hasil penyelidikan peserta didik dengan diskusi untuk diberikan masukan dan disimpulkan oleh seluruh kelas terkait dengan ketepatan unsur kebahasaan teks LHO yang telah dikerjakan setiap kelompok. Dosen memberikan penguatan materi yang berkaitan dengan pekerjaan setiap kelompok. Dosen memberikan apresiasi positif bagi kelompok yang aktif dan tepat dalam mengerjakan lembar kerja yang diberikan.

\section{Peningkatan Kemampuan Siswa dalam Menganalisis Aspek Kebahasaan Teks Laporan Hasil Observasi dengan Menggunakan Video Berbasis Teks dan Keranjang Bahasa pada Siswa $X$ MIPA 2 SMAN 7 Malang}

Pada bagian ini, dijelaskan deskripsi dan perhitungan nilai evaluasi siswa pada siklus 1 dan 2 . Pada siklus 1 , ketika menerima tugas kelompok, siswa masih merasa kebingungan karena kurang dapat memahami instruksi. Selain itu, guru belum memberikan contoh pengerjaan dari tugas tersebut. Para siswa dapat bekerja sama dalam kelompok, tetapi masih terdapat sedikit siswa yang masih tampak malu dan kurang terlibat dalam kerja kelompok. Dari enam kelompok yang ada, empat kelompok memiliki anggota yang masing-masing bekerja sama dengan baik. Pada satu kelompok yang lain, tiga siswa aktif mengerjakan tetapi satu siswa lainnya tampak malu. Sementara itu, terdapat satu kelompok yang bekerja sama tetapi kurang jelas pembagian tugasnya sehingga ada satu siswa yang mengerjakan sedangkan siswa lainnya berdiskusi tetapi kurang kolaboratif. Pada proses menganalisis aspek kebahasaan, rata-rata dalam setiap kelompok hanya mampu menemukan sifat bahasa dalam laoran hasil observasi secara umum saja. Para siswa menemukan beberapa hal, yaitu (1) bahasa yang digunakan adalah bahasa yang formal dan baku, (2) kata adalah, merupakan, dan ialah digunakan pada kalimat definisi, serta (3) kata yaitu, seperti, dan antara lain digunakan dalam menyebutkan kelompok informasi pada struktur deskripsi bagian. Akan tetapi, aspek kebahasaan secara lebih rinci tentang kata, frasa, klausa, dan kalimat belum ditemukan oleh masing-masing kelompok. Oleh karena itu, dibutuhkan tindak lanjut untuk meningkatkan proses dan hasil belajar siswa pada siklus 2 .

Pada siklus 2, setiap siswa terlibat aktif dalam menganalisis aspek kebahasaan teks laporan hasil observasi karena setiap siswa punya kesempatan mengambil kartu kata, frasa, atau kalimat secara acak dari bank bahasa dan memasukkannya pada keranjang bahasa sesuai klasifikasinya. Siswa juga lebih cepat dalam menentukan apakah kartu tersebut termasuk kata, frasa, atau kalimat. Berkaitan dengan hal itu, Admiraal dkk. (2011:1185) menyatakan bahwa karakteristik siswa menengah atas cenderung mudah bosan dan kurang berkomitmen terhadap proses pembelajaran. Oleh karena itu, pembelajaran perlu didesain dengan mengedepankan situasi pembelajaran yang menyenangkan dan mengandung tantangan. Salah satu desain yang dapat dikembangkan adalahpermainan berbasis pembelajaran sebagaimana tampak pada penggunaan media keranjang bahasa yang memfasilitasi proses pembelajaran yang menyenangkan melalui permainan sederhana.

Sugiarti, Arti Prihatini, Fida Pangesti, Penggunaan Video Berbasis Teks dan Keranjang Bahasa untuk Meningkatkan Kemampuan Siswa dalam Menganalisis Aspek Kebahasaan Laporan Hasil 
Pada kegiatan mengisi lembar kerja berdasarkan kartu-kartu yang telah dimasukkan pada keranjang bahasa, para siswa mampu menyimpulkan konsep/ definisi dari kata, frasa endosentris, frasa eksosentris, kalimat simpleks, dan kalimat kompleks dari kartu-kartu yang mereka analisis. Jadi, siswa dapat menemukan pemahamannya sendiri dari penggunaan media keranjang bahasa tersebut melalui kerja kelompok. Siswa juga dapat mencari contoh lain dari kata, frasa, dan kalimat dari teks laporan hasil observasi yang disertakan pada lembar kerja. Selain itu, siswa juga dapat mengakses materi tentang aspek kebahasaan teks laporan hasil observasi melalui link youtube yang sudah dibagikan pada siswa sehingga siswa dapat belajar secara mandiri dimana saja dan kapan saja. Hal itu sesuai dengan yang dikemukakan Nepo (2017:207) bahwa teknologi menjadi bagian dari program pendidikan yang berorientasi pada peran individu siswa. Jadi, siswa dapat secara mandiri mempelajari materi tersebut.

Pada siklus 2 tersebut, dapat dikatakan bahwa siswa tidak kehilangan peran individunya dalam memeroleh pemahaman aspek kebahasaan melalui media keranjang bahasa. Siswa berperan secara individu menentukan kartu dalam kategori kata, frasa, dan kalimat. Secara berkelompok, para siswa mengisi lembar kerja dari kartu di keranjang bahasa yang telah ditentukannya sebelumnya.
Hal itu sesuai dengan Admiraal dkk (2011:1186) bahwa faktor individual dan faktor interpersonal yang dapat mendorong motivasi intrinsik siswa. Motivasi intrinsik yang di desain dengan pembelajaran itulah yang berdampak pada kompetensi siswa.

Dengan memperhatikan hasil evaluasi yang di lakukan, dapat diperhatikan ada kenaikan yang cukup signifikan dari siklus 1 ke siklus 2 . Pada siklus 1, terdapat sebagian siswa yang belum tuntas dalam pembelajaran karena tidak memenuhi kriteria kelulusan minimal (KKM), yakni 75 . Pada siklus 2, dari keseluruhan peserta didik (24 orang) pada tugas analisis jenis kata $100 \%$ siswa memenuhi KKM , demikian pula jenis frasa, jenis kalimat dan analisis kesalahan bahasa. Berkaitan dengan hal itu, Nepo (2017:213) menyatakan bahwa tujuan utama pembelajaran adalah untuk memaksimalkan potensi pada semua siswa. Hal itu terbukti dari tercapainya KKM pada hasil belajar semua siswa pada siklus 2. Hal itu juga menunjukkan bahwa penggunaan video berbasis teks dan media keranjang bahasa dapat membantu siswa meningkatkan kemampuannya dalam memahami aspek kebahasaan teks laporan hasil observasi.

Berikut ini adalah tabel hasil belajar siklus 1 yang selanjutnya dicantumkan pula tabel hasil belajar siklus 2 . 
Tabel 1. Hasil Belajar Siklus 1

\begin{tabular}{|c|c|c|c|c|}
\hline \multirow[b]{2}{*}{$\begin{array}{l}\text { Kode Nama } \\
\text { Siswa }\end{array}$} & \multicolumn{4}{|c|}{ Aspek yang Dikaji dan Perolehan Skor } \\
\hline & $\begin{array}{c}\text { Analisis } \\
\text { Jenis Kata }\end{array}$ & $\begin{array}{l}\text { Analisis } \\
\text { Jenis Frasa }\end{array}$ & $\begin{array}{l}\text { Analisis Jenis } \\
\text { Kalimat }\end{array}$ & $\begin{array}{c}\text { Analisis Kesalahan } \\
\text { Bahasa }\end{array}$ \\
\hline BT & 70 & 70 & 70 & 75 \\
\hline $\mathrm{HK}$ & 70 & 70 & 70 & 75 \\
\hline IL & 85 & 70 & 70 & 75 \\
\hline MK & 80 & 70 & 75 & 75 \\
\hline MB & 85 & 70 & 75 & 75 \\
\hline NR & 70 & 70 & 65 & 75 \\
\hline $\mathrm{BR}$ & 80 & 70 & 78 & 75 \\
\hline EV & 65 & 70 & 78 & 75 \\
\hline IP & 80 & 70 & 78 & 75 \\
\hline NF & 70 & 70 & 65 & 75 \\
\hline RF & 80 & 70 & 65 & 75 \\
\hline SK & 65 & 70 & 65 & 75 \\
\hline AA & 80 & 70 & 70 & 75 \\
\hline $\mathrm{AD}$ & 70 & 70 & 70 & 75 \\
\hline IT & 70 & 70 & 70 & 75 \\
\hline NZ & 70 & 70 & 60 & 75 \\
\hline SB & 75 & 70 & 60 & 75 \\
\hline VA & 70 & 70 & 70 & 75 \\
\hline $\mathrm{AR}$ & 70 & 70 & 70 & 75 \\
\hline DO & 82 & 70 & 65 & 75 \\
\hline $\mathrm{KH}$ & 72 & 70 & 65 & 75 \\
\hline AL & 82 & 70 & 75 & 75 \\
\hline $\mathrm{PC}$ & 72 & 70 & 75 & 75 \\
\hline $\mathrm{RN}$ & 72 & 70 & 75 & 75 \\
\hline Jumlah & 1785 & 1680 & 1679 & 1800 \\
\hline Rata-rata & 74.375 & 70 & 69.95833 & 75 \\
\hline$\geq \mathrm{KKM}$ & $41,7 \%$ & $0 \%$ & $33,3 \%$ & $100 \%$ \\
\hline$<\mathrm{KKM}$ & $58,3 \%$ & $100 \%$ & $66,7 \%$ & $0 \%$ \\
\hline
\end{tabular}

Sumber: Data Penelitian SMAN 7 Malang, 2018

Berdasarkan data tersebut, dapat diketahui bahwa tidak ada siswa yang mendapat skor maksimal. Meskipun media yang digunakan menarik, persentase ketuntasan belajar cukup rendah, yakni 58,3\% siswa tidak tuntas KKM pada analisis kata, $100 \%$ siswa tidak tuntas KKM pada analisis frasa, $66,7 \%$ siswa tidak tuntas KKM pada analisis kalimat, dan $0 \%$ siswa tidak tuntas KKM pada analisis kesalahan berbahasa. Siswa belum optimal dalam menentukan jenis kata, jenis frasa, dan jenis kalimat. Siswa juga kesulitan dalam menganalisis kesalahan bahasa laporan hasil observasi. Hal ini didukung hasil wawancara yang menunjukkan bahwa siswa merasa media sudah menarik, tetapi dari aspek pemahaman masih mengalami kesulitan. 
Tabel 2. Hasil Belajar Siklus 2

\begin{tabular}{|c|c|c|c|c|}
\hline \multirow{4}{*}{$\begin{array}{c}\text { Kode Nama } \\
\text { Siswa }\end{array}$} & \multicolumn{4}{|c|}{ Aspek yang Dikaji dan Perolehan Skor } \\
\hline & Analisis & Analisis & Analisis Jenis & Analisis \\
\hline & Jenis Kata & Jenis Frasa & Kalimat & Kesalahan \\
\hline & & & & Bahasa \\
\hline BT & 85 & 80 & 75 & 75 \\
\hline $\mathrm{HK}$ & 85 & 80 & 75 & 75 \\
\hline IL & 85 & 80 & 75 & 75 \\
\hline MK & 85 & 80 & 75 & 75 \\
\hline MB & 85 & 80 & 75 & 75 \\
\hline NR & 85 & 80 & 75 & 75 \\
\hline BR & 80 & 80 & 78 & 75 \\
\hline $\mathrm{EV}$ & 80 & 80 & 78 & 75 \\
\hline IP & 80 & 80 & 78 & 75 \\
\hline $\mathrm{NF}$ & 80 & 80 & 78 & 75 \\
\hline $\mathrm{RF}$ & 80 & 80 & 78 & 75 \\
\hline SK & 80 & 80 & 78 & 75 \\
\hline AA & 83 & 80 & 79 & 75 \\
\hline $\mathrm{AD}$ & 83 & 80 & 79 & 75 \\
\hline IT & 83 & 80 & 79 & 75 \\
\hline $\mathrm{NZ}$ & 83 & 80 & 79 & 75 \\
\hline SB & 83 & 80 & 79 & 75 \\
\hline VA & 83 & 80 & 79 & 75 \\
\hline $\mathrm{AR}$ & 82 & 80 & 75 & 75 \\
\hline DO & 82 & 80 & 75 & 75 \\
\hline $\mathrm{KH}$ & 82 & 80 & 75 & 75 \\
\hline $\mathrm{AL}$ & 82 & 80 & 75 & 75 \\
\hline $\mathrm{PC}$ & 82 & 80 & 75 & 75 \\
\hline $\mathrm{RN}$ & 82 & 80 & 75 & 75 \\
\hline Jumlah & 1980 & 1920 & 1842 & 1800 \\
\hline Rata-rata & 82.5 & 80 & 76.75 & 75 \\
\hline$\geq \mathrm{KKM}$ & $100 \%$ & $100 \%$ & $100 \%$ & $100 \%$ \\
\hline$<\mathrm{KKM}$ & $0 \%$ & $0 \%$ & $0 \%$ & $0 \%$ \\
\hline
\end{tabular}

Sumber: Data Penelitian SMAN 7 Malang, 2018

Berdasarkan dua tabel tersebut, dapat disimpulkan bahwa penggunaan media video berbasis teks dan keranjang bahasa dapat meningkatkan kemampuan siswa dalam menganalisis aspek kebahasaan laporan hasil observasi. Media yang digunakan sangat menarik sehingga memotivasi siswa untuk belajar. Media sangat mendukung untuk meningkatkan interaksi antarsiswa.
Menurut guru sebagai observer, siswa tertarik dalam pembelajaran dengan media yang digunakan. Materi yang disajikan melalui video sesuai dengan pembelajaran. Penggunaan video ini juga sesuai dengan karakter siswa yang dekat dengan teknologi. Hal itu sesuai dengan Lau, Lakhan, dan Achike (2018:457) tentang syarat penggunaan teknologi dalam pembelajaran agar 
berdampak secara efektif bahwa pemanfaatan teknologi perlu disesuaikan dengan materi pembelajaran dan juga didasarkan pada karakteristik siswa.

Lebih lanjut, guru mengungkapkan bahwa model pembelajaran yang dipilih membuat interaksi antarsiswa cukup tinggi karena siswa harus berbagi tugas dan berdiskusi dengan teman satu kelompok. Hal ini dipertegas dari hasil wawancara dengan guru melalui observasi kelas diperoleh informasi bahwa siwa termotivasi dengan pembelajaran yang dilakukan guru karena model pembelajaran berpusat pada peserta didik dengan strategi pembelajaran group learning sangat sesuai. Berkaitan dengan hal itu, O'Malley, Voight, dan Izu (2014: 338), siswa terfokus pada hubungan antarteman sebagai area yang dapat digunakan untuk proses peningkatan atau kemajuan diri. Sehubungan dengan hal itu, Wentzel, Russell, dan Baker (2014:268) juga menegaskan kelompok dapat memfasilitasi pengembangan hubungan sosial yang positif dan hasil belajar siswa.

Evaluasi dilakukan untuk menguatkan interaksi antarsiswa dan interaksi siswa dengan guru. LKPD (Lembar Kerja Peserta Didik) sebagai alat evaluasi sangat membantu siswa dalam menyelesaikan tugas dalam satu kelompok. Siswa semakin kreatif dalam penyelesaian LKPD sesuai dengan target pembelajaran yang dilakukan. Di samping itu, siswa termotivasi dalam penyelesaian tugas-tugas yang telah diberikan guru. LKPD disusun dengan memperhatikan tingkat kesulitan soal sehingga LKPD terdiri atas soal yang mudah, sedang, hingga sulit. Hal itu dilakukan agar siswa dapat menguasai aspek kebahasaan teks laporan hasil observasi secara lebih komprehensif. Berkaitan dengan hal itu, Arends (2015:166) menjelaskan bahwa faktor tambahan yang dapat memengaruhi motivasi siswa yang terkait dengan tingkat kesulitan yang bervariasi pada soal-soal dalam evaluasi. Hal itu disebabkan evaluasi yang terlalu mudah membutuhkan usaha yang sedikit sehingga menghasilkan perasaan sukses yang kecil. Meskipun tingkat kesulitan soal bervariasi, siswa tetap termotivasi mengerjakannya karena LKPD diiringi dengan kegiatan yang menyenangkan dengan menggunakan media keranjang bahasa.

Berdasarkan kedua tabel tersebut, terdapat peningkatan kemampuan siswa dalam menganalisis aspek kebahasaan teks laporan hasil observasi. Berikut ini adalah diagram dan tabel peningkatan kemampuan siswa dalam aspek kebahasaan teks laporan hasil observasi. 


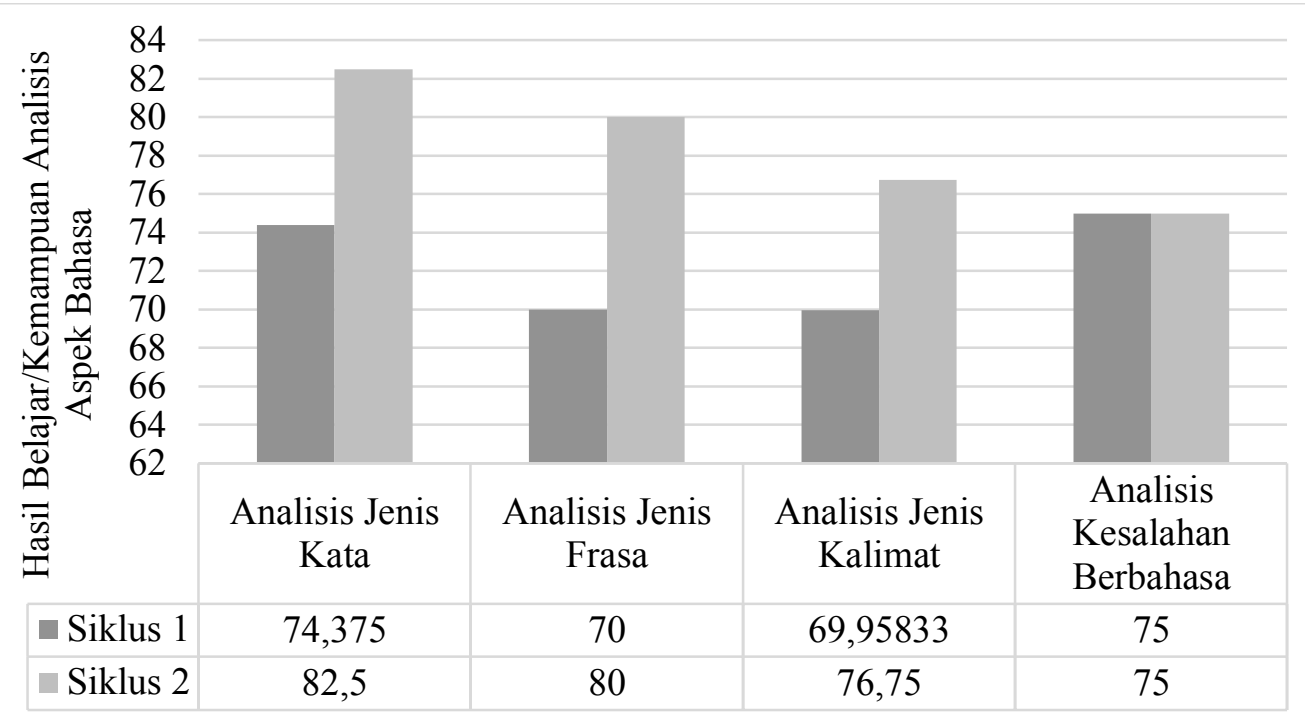

Gambar 5. Peningkatan Kemampuan Siswa dari Siklus 1 ke Siklus 2

Berdasarkan diagram berikut, aspek kebahasaan teks laporan hasil berikut ini tabel peningkatan observasi. kemampuan siswa dalam menganalisis

Tabel 3. Persentase Peningkatan Kemampuan Siswa

\begin{tabular}{lccc}
\hline \multicolumn{1}{c}{ Aspek yang Dinilai } & $\begin{array}{c}\text { Rata-rata } \\
\text { Siklus 1 }\end{array}$ & $\begin{array}{c}\text { Rata-rata } \\
\text { Siklus 2 }\end{array}$ & Peningkatan \\
\hline Analisis Jenis Kata & 74.375 & 82.5 & $11 \%$ \\
\hline Analisis Jenis Frasa & 70 & 80 & $14 \%$ \\
\hline Analisis Jenis Kalimat & 69.95833 & 76.75 & $10 \%$ \\
\hline Analisis Kesalahan & 75 & 75 & $0 \%$ \\
Bahasa & & & \\
\hline
\end{tabular}

Berdasarkan diagram dan tabel tersebut, peningkatan kemampuan siswa terjadi pada aspek analisis jenis kata $(11 \%)$, analisis jenis frasa $(14 \%)$, dan analisis jenis kalimat (10\%). Sementara itu, aspek analisis kesalahan bahasa sama, yakni $0 \%$. Jadi, dapat disimpulkan bahwa semua siswa telah memenuhi standar KKM dan terjadi peningkatan kompetensi siswa dalam menganalisis aspek kebahasaan teks laporan hasil observasi.

\section{SIMPULAN}

Berdasarkan uraian pembahasan, dapat dikemukakan simpulan bahwa (1) pada siklus 1 dengan menggunakan video berbasis teks dengan diskusi kelompok, siswa belum dapat secara optimal dalam menganalisis aspek kebahasaan laporan hasil observasi. Hal itu ditunjukkan oleh rata-rata hasil belajar siswa, yakni 74,375 (kata), 70 (frasa), 69,95 (kalimat), dan 75 (kesalahan berbahasa); serta pada siklus 2, penggunaan video berbasis teks dan keranjang bahasa dengan model permainan berkelompok berdampak pada keterlibatan siswa secara aktif, tepat, dan cepat dalam menganalisis aspek kebahasaan laporan hasil observasi (jenis kata, jenis frasa, jenis kalimat, dan kesalahan berbahasa). Pada akhirnya, kemampuan siswa dalam menganalisis aspek kebahasaan 
meningkat antara 10-14 \%, yakni 82.5 (kata), 80 (frasa), 76.75 (kalimat), dan 75 (kesalahan berbahasa). Hal itu menunjukkan bahwa penggunaan video berbasis teks dan keranjang bahasa dapat meningkatkan kemampuan siswa dalam menganalisis aspek kebahasaan teks laporan hasil observasi.

\section{DAFTAR PUSTAKA}

Admiraal, Willfried dkk. 2011. The Concept of Flow in Collaborative Game-Based Learning. Computers in Human Behavior 27(3): 11851194.

Arends, Richard I. 2015. Learning to Teach Tenth Edition. New York: McGraw-Hill Education.

Efendi, A. (ed). 2008. Bahasa dan Sastra dalam Berbagai Perspektif. Yogyakarta: Fakultas Bahasa dan Seni Universitas Negeri Yogyakarta Tiara Wacana.

Garim, Idawati dkk. 2017. Morphology and Syntax of Tae' Language. The 1st International Conference on Education, Science, Art and Technology (the 1st ICESAT) Universitas Negeri Makassar. 22 23 July 2017: 88-97.

Gilakjani, Abbas Pourhossein dan Ahmadi, Sayedeh Masoumeh. 2011. The Effect of Visual, Auditory, and Kinaesthetic Learning Styles on Language Teaching. 2011 International Conference on Social Science and Humanity IPEDR Vol. 5: 469-472. Singapore: IACSIT Press.

Lau, K. H. Vincent; Lakhan, Shaheen E.; dan Achike, Francis. 2018. New Media, Technology, and Neurology Education. Seminars in Neurology Vol. 38 (4): 457-464.
Nepo, Kaori. 2017. The Use of Technology to Improve Education. Child Youth Care Forum 46: 207221.

O’Malley, Meagan; Voight, Adam; \& Izu, Jo Ann. 2014. Engaging Students in School Climate Improvement: A Student Voice Strategy. Furlong, Michael J.; Gilman, Rich; \& Huebner, E. Scott. (Eds.) Handbook of Positive Psychology in School Second Edition. New York: Routledge. 329-346

Santrock, John W. 2012. Educational Psychology Fifth Edition. New York: McGraw-Hill Education.

Simunic, Dina'; Kerner, Antun; dan Gajovic, Srecko. 2018. Digital Mediators as Key Enablers of Navigation Towards Health in Knowledge Landscapes. Croation Medical Journal 59: 178-82.

Sneddon, J. N. dkk. 2010. Indonesian: A Reference Grammar 2nd Edition. Sydney: Allen \& Unwin.

Sugiarti. 2016. Pembelajaran Bahasa dan Sastra di Sekolah: Makalah dipresentasikan pada Seminar Regional Kerjasama Kemitraan Bidang Kebahasaan dan Kesastraan Balai Bahasa Jawa Timur dengan Prodi Pendidikan Bahasa dan Sastra Indonesia FKIP Universitas Muhammadiyah Malang, Malang 13 Agustus 2016.

Wentzel, Kathryn; Russell, Shannon; \& Baker, Sandra. 2014. Peer Relationships and Positive Adjustment at School. Furlong, Michael J.; Gilman, Rich; \& Huebner, E. Scott. (Eds.) Handbook of Positive Psychology in School Second Edition. New York: Routledge. 260-277. 
Xhemajli, Arbonna. 2016. The Role of The Teacher in Interactive Teaching. International Journal of Cognitive Research in Science, Engineering, and Education Vol. 4 (1): 31-38. 